\title{
Financial Performance in the Public Administration Sector: Comparison Between Hungary and Romania
}

\author{
MATEI T $\breve{M}$ ĂŞIL $\breve{A}$ \\ Politehnica University of Timisoara, Romania \\ matei.tamasila@upt.ro \\ ILIE MIHAI TĂUCEAN \\ Politehnica University of Timisoara, Romania \\ ilie.taucean@upt.ro \\ ALIN EMANUEL ARTENE \\ Politehnica University of Timisoara, Romania \\ alin.artene@upt.ro \\ CLAUDIU TIBERIU ALBULESCU \\ Politehnica University of Timisoara, Romania \\ claudiu.albulescu@upt.ro
}

We investigate the long-run relationship between profitability, liquidity and capitalization for companies acting in the public administration and defense sector from Hungary and Romania, using firm-level data for the period 2006-2015. Our panel cointegration analysis proves the existence of a long-run relationship between the analyzed variables. The Dols results posit in the favor of a trade-off between liquidity and profitability for Hungary, but not for Romania. At the same time, the capitalization ratio negatively impacts the profitability ratio in Romania. These results are validated by a series of robustness tests, considering different profitability indicators, and partially validated by the FMOLs analysis. Our findings have noteworthy implications for the financial management of companies acting in the field of public administration and defense, showing different financial management strategies for the companies located in the two analyzed countries.

Key words: financial performance, public administration sector, firm-level data, panel cointegration

https://doi.org/10.26493/1854-4231.13.197-211

\section{Introduction}

The nexus between profitability and liquidity represents a challenge for the optimization of companies' financial decisions. Previous literature shows that firms' financial management might have different approaches to increase the financial performances, or the level 
of profitability. A first theory states that more liquid firms are, more they can fulfill they short-term obligations and increase their sales. This way firms may obtain higher discounts for early payments that ensure an increase of the profitability level (Deloof 2003). In addition, short-term liquidity sources help firms to deal with unexpected situations and to take advantage of investment opportunities, especially during economic downturn periods. This is more evident for financially constrained firms. The second theory states that higher liquidity means unemployed resources. Therefore, liquidity might endanger profitability, and a trade-off appears between liquidity and profitability (Bolek and Wilinski, 2012). Otherwise said, firms that look for profitability are determined to have a small amount of current assets (i.e. cash, inventories and trade receivables). Ukaegbu (2014) provides a reconciliation between these opposite theories. The author underlines the necessary distinction between fluctuating current assets (to be financed by short-term financial sources) and permanent current assets (to be financed by long-term sources). In addition, in economic downturn periods, it is important to have an acceptable liquidity level (Albulescu et al., 2016). As Korajczyk and Levy (2003) show, recessions put pressure on liquidity and firms may react differently to the macroeconomic context and new financial conditions.

The empirical literature shows mixed evidence when assessing the profitability - liquidity nexus. Most of firm-level applications consider, beside profitability and liquidity, the role of working capital. In this line, Smith and Begemann (1997) report for a set of South African firms that the current liquidity ratio and the quick liquidity ratio have no significant impact on the profitability level. Other studies (e.g. Raheman and Nasr, 2007; Gill, Bigger, and Mathur 2010) report a negative impact of the working capital and liquidity on the profitability level. Opposite findings are advanced by Akinlo (2011) who tests the existence of a long-run relationship between profitability and liquidity for 66 Nigerian firms and discovers a positive effect.

At the same time, the capitalization level might have in its turn a mixed effect on profitability. A good capitalization helps companies to fulfill their long-term obligations. Therefore, on the one hand, this can be a good sign for investors and creditors, facilitating the firms' access to finance and fostering thus the profitability. However, on the other hand, firms may encounter higher costs with dividends as compared with loans' interest. In this case, if internal financial sources imply higher costs than external ones, the level of profitabil- 
ity might decrease. We further on test these opposite theories by focusing on the firms acting in public administration and defense sector from Hungary and Romania. We perform a comparison between the two countries to see how liquidity and capitalization interact with the profitability level for firms which are state-dependent for doing business, and to see which the particularities of this relationship are in the post-crisis period. For this purpose, we use firm-level data from 2006 to 2015, resorting to AMADEUS statistics.

Different from similar works, we check for the existence of a longrun relationship between profitability on the one hand, and liquidity and capitalization on the other hand (using the Kao's (1999) test for panel cointegration). This relationship is afterwards estimated via the Dynamic Ordinary Least Square (DoLs) regression developed by Kao and Chiang (2000) for homogenous panels, and by the Fully Modified Ordinary Least Square (FMOLS) regression, designed for heterogenous panels, advanced by Pedroni (2000). For robustness purposes, we use alternative metrics for the level of profitability, as well as for the liquidity level.

The rest of the paper is as follows. The next section presents a short literature review. The third section addresses the data and the methodology. The forth section presents the empirical results while the fifth section addresses the robustness analysis of our empirical findings. The last section draws the conclusions.

\section{Literature Review}

The optimization of firms' financial decisions represents one of the central focus of the financial management literature. Two main internal elements influence the companies' profitability level. On the one hand, on the assets side, the way firms operate their business influence their success. Companies should be prepared to fulfill the unexpected financial obligations, and to take advantage from investment opportunities as quick as possible. This can be achieved if a sufficient level of liquidity is ensured. A high level of liquidity is particularly important in crisis times, when the access to external financing sources is restricted, or when interesting investment opportunities appear. At the same time, if the operating assets as cash, inventory or accounts receivable are too high, important resources remain unused, and might diminished the companies' profitability level. This trade-off can be better explained comparing the situation of financially constrained and unconstrained firms (Perobelli, Famá, and Sacramento 2016).

On the other hand, the structure of financing sources may influ- 
ence the level of profitability. The choice between internal and external financing sources is made considering the financing costs. The financial management usually resorts to internal sources to finance the business. In this case, a high capitalization level might be equivalent with cheaper financing sources, which help to increase financial performances. A high capitalization level, associated with a good solvability, is also a sign of financial soundness and might be useful to attract new investors in the case of listed companies. However, if the internal financing sources are more expensive compared with the external ones, given the level of dividend taxes for example, a high capitalization level and therefore the use of internal sources in the detriment of external ones as bank loans, might negatively influence the profitability level.

The empirical literature usually assesses the interdependence between liquidity and profitability, which might be considered as two conflicting goals of working capital management (Smith and Begemann 1997). For example, Perobelli, Famá, and Sacramento (2016) investigate different theories for the profitability - liquidity relationship, considering 872 shares of publicly-traded Brazilian companies, between 1994 and 2013. Adhikary and Papachristou (2017) search for a panel of 114 microfinance firms from South Asia, the determinants of profitability, for the period 2003 to 2011. They show that a strong capitalization, liquidity, and an increased industry concentration, are positively related with the profitability level.

Noteworthy studies focus on the working capital as a proxy for the liquidity level. In this line, Raheman and Nasr (2007) and Gill, Bigger, and Mathur (2010) find a negative relationship between the working capital and the profitability level. Similar findings are reported by Wasiuzzaman (2015) who uses a sample of 160 manufacturing firms in Malaysia, and an ordinary least squares (ols) regression technique. The author's investigation shows a negative relationship between working capital (and its components) and profitability. For a set of 66 Nigerian firms Akinlo (2011) reports on contrary, a positive long-run relationship between profitability and liquidity. These results are sustained by Akinlo (2012). For the same set of companies for the period 1997-2007, the author considers the cash conversion cycle as a comprehensive measure of working capital management and suggest that firms' profitability is reduced by lengthening the number of days accounts receivable.

The relationship between capitalization and profitability is particularly important for the banking industry, given the role of regulatory capital in banks' activity. This relationship is equally impor- 
tant firms, as the capitalization ratio provides information about the structure of financing sources. At the same time, from the accounting point of view, a high capitalization ratio is associated with a small leverage ratio. Higher the leverage is, more a company depends on long-term creditors for its long-term capital (Murphy 1968). Therefore, the impact on profitability depends on the trade-off between the internal and external financing sources. Given the fact that not all the companies report the level of their loans and credits, from an empirical point of view the analysis of the capitalization impact on profitability level seems to be recommended. In this line, Ghosh (2008) discovers that by taking more debt relative to own assets, firms' profits decrease. For a sample of 21 Pakistani cement companies listed on Karachi Stock Exchange for the period 2007 to 2012, Iqbal, Mulani, and Kabiraj (2013) show that there is a strong negative relationship between leverage and profitability of the firm (or a strong positive relationship between capitalization and profitability).

However, none of the aforementioned papers addresses the case of companies from the public administration and defense sector, nor they perform a comparative analysis at international level. To fill in this gap, we compare the financial management strategies of companies from Hungary and Romania.

\section{Data and Methodology}

DATA

We use AMADE US annual data from 2006 to 2015, considering private and public companies acting in the field of 'Public administration and defense; compulsory social security' (NACE code 84). We analyze to what extent their capacity to manage short and long-term obligations affects their profitability, drawing a comparison between Hungary and Romania. We have retained into analysis only those companies for which we found at least five years of observations (we have therefore obtained an unbalanced panel). In Hungary, 22 companies were registered in 2015 in this services field. We have found satisfactory data for half of them (11 firms). In Romania, 33 companies are recorded in this industry in 2015, out of which 17 are retained into analysis. The list of the companies is presented in table 1.

The profitability of these companies is assessed using the return on equity ratio. In the main analysis, in line with similar papers, we resort to the return on equity ratio calculated based on net income (ROEni):

$$
\operatorname{ROE} \operatorname{ni}(\%)=\frac{\mathrm{NI}}{\mathrm{E}} \%,
$$


TABLE 1 List of Companies Included in the Study

\begin{tabular}{ll}
\hline Hungary & 1. Cordate \\
2. Ddrfü \\
3. Körösfront \\
4. M3 Road \\
5. Magyar Alkotóművészeti Közhasznú \\
6. Magyar Nemzeti Filmalap Közhasznú \\
7. MIL-Exı́ \\
8. Norda Észak \\
9. Pajzs '94' \\
10. Pro Rekreatione Közhasznú \\
11. Value Added Solutions Consulting \\
1. Administratia Domeniului Public si Privat Giurgiu \\
2. Alfa Point Protect sRL \\
3. AMA Consultanta si Servicii \\
4. Compania Nationala de Administrare a Infrastructurii Rutiere \\
5. Compania Stingeri si Interventii \\
6. Davi Comfire \\
7. Electromagnetica Fire \\
8. Falck Fire Services \\
9. Fireproof Team \\
10. Geo-Sting \\
11. Gepro \\
12. Interprev Crist \\
13. NEI Fire Protection \\
14 Parc Industrial Mija \\
15. Parc Tehnologic si Industrial Giurgiu Nord \\
16. Preventfire \\
17. Regia Autonoma de Servicii Publice Ploiesti \\
\end{tabular}

where NI represents the net income and $\mathrm{E}$ is the average total equity for the year.

In our robustness analysis, we use two alternative metrics for profitability, namely return on equity ratio calculated using the level of profit before tax (ROE pbf), and the return on assets ratio calculated using the level of profit before tax (ROApbf):

$$
\operatorname{ROE} \operatorname{pbt}(\%)=\frac{\mathrm{EBIT}}{\mathrm{E}} \% \text {, }
$$

where ввт represents the earnings before income taxes.

$$
\operatorname{ROApbt}(\%)=\frac{\text { EBIT }}{\mathrm{TA}},
$$

where TA are the total assets of the company.

In terms of explanatory variables, we consider two alternative metrics, namely the general liquidity ratio (LR) and the current ratio (CR): 
TABLE 2 Summary Statistics

\begin{tabular}{lrrrrrrr}
\hline Country & & ROEni & ROEpbt & ROApbt & LR & CR & SER \\
\hline Hungary & $(1)$ & 21.32289 & 20.87972 & 7.972772 & 2.674272 & 2.972544 & 38.36221 \\
& $(2)$ & 18.31500 & 18.95700 & 4.475000 & 1.339000 & 1.460000 & 38.83200 \\
& $(3)$ & 98.59800 & 339.7150 & 44.49400 & 40.85700 & 45.78500 & 87.52600 \\
& $(4)$ & -76.00800 & -193.7550 & -7.063000 & 0.029000 & 0.029000 & 0.365000 \\
& $(5)$ & 31.02288 & 63.29523 & 10.90103 & 6.075432 & 6.638432 & 27.79668 \\
& $(6)$ & 0.404938 & 1.687614 & 1.321158 & 5.163889 & 5.334920 & 0.165771 \\
& $(7)$ & 4.645913 & 14.76823 & 4.445159 & 30.79581 & 33.06083 & 1.839647 \\
\hline Romania & $(1)$ & 35.04374 & 44.64911 & 15.81922 & 1.964355 & 1.863652 & 41.84619 \\
& $(2)$ & 31.12350 & 37.65400 & 13.19850 & 1.355000 & 1.372500 & 43.02350 \\
& $(3)$ & 184.6310 & 236.6000 & 84.20600 & 10.51000 & 11.09100 & 93.64500 \\
& $(4)$ & -81.28400 & -81.27900 & -16.68000 & 0.050000 & 0.071000 & 1.212000 \\
& $(5)$ & 34.83133 & 44.77107 & 17.49132 & 1.639162 & 1.579840 & 23.15735 \\
& $(6)$ & 0.547306 & 0.892182 & 1.261623 & 1.874644 & 2.150136 & 0.127147 \\
& $(7)$ & 4.865546 & 5.126120 & 5.025017 & 7.895040 & 10.70493 & 2.060948 \\
\hline
\end{tabular}

Notes Row headings are as follows: (1) mean, (2) median, (3) maximum, (4) minimum, (5) standard deviation, (6) skewness, (7) kurtosis.

$$
\mathrm{LR}(\%)=\frac{\mathrm{OA}}{\mathrm{CL}}
$$

where $\mathrm{OA}$ are the operating assets and CL are the current liabilities.

$$
\mathrm{CR}(\%)=\frac{\mathrm{CA}}{\mathrm{CL}},
$$

where cA are the current assets or the difference between operating assets and non-current assets.

Finally, the capitalization is assessed considering the shareholder equity ratio as follows:

$$
\operatorname{SER}(\%)=\frac{\mathrm{E}}{\mathrm{TA}}
$$

where CA are the current assets, or the difference between operating assets and non-current assets.

Table 2 presents the descriptive statistics of the sample. We notice that the profitability of the Romanian companies is higher in comparison with those from Hungary, while the liquidity is smaller. We also notice that the financial indicators' volatility is higher in Hungary. Finally, data are positively skewed but nor far from the normal distribution. However, the data shows excess kurtosis for liquidity ratio, in particular for Hungary, indicating the existence of leptokurtic densities.

We start our analysis with a series of cross-sectional dependence 
TABLE 3 Cross-Sectional Dependence Tests

\begin{tabular}{|c|c|c|c|c|c|c|c|c|c|}
\hline \multirow[t]{2}{*}{ Country } & \multirow{2}{*}{\multicolumn{2}{|c|}{ Pesaran CD Norm. }} & \multirow{2}{*}{\multicolumn{2}{|c|}{ Friedman $\chi^{2}$}} & \multicolumn{5}{|c|}{ Frees Normal } \\
\hline & & & & & \multicolumn{2}{|c|}{ Test } & $10 \%$ & $5 \%$ & $1 \%$ \\
\hline \multicolumn{2}{|l|}{ Romania } & $0.106(0.915)$ & \multicolumn{2}{|c|}{$4.571(0.995)$} & & 67 & 0.412 & 0.567 & 0.902 \\
\hline \multicolumn{10}{|c|}{$\begin{array}{l}\text { NOTES The null hypothesis is no cross-sectional dependence; for Hungary, the num- } \\
\text { ber of observations contained by the unbalanced panel is insufficient to perform } \\
\text { cross-sectional dependence tests. }\end{array}$} \\
\hline \multicolumn{10}{|c|}{ TABLE 4 Panel Unit Root Tests } \\
\hline Country & & RoEni & ROEpbt & ROApb & & & $\mathbf{R}$ & $\mathrm{CR}$ & SER \\
\hline \multirow[t]{4}{*}{ Hungary } & (1) & $-9 \cdot 395^{* * *}$ & $-10.60^{* * *}$ & -11.3 & & & & 0.773 & $-5 \cdot 726^{* *}$ \\
\hline & (2) & $-3.233^{* * *}$ & $-4 \cdot 337^{* * *}$ & -3.22 & & $-\mathrm{O}$. & & -0.027 & $-1.420^{*}$ \\
\hline & (3) & $27.23^{* * *}$ & $32.44^{* * *}$ & 24.1 & & & & 7.996 & $15 \cdot 51^{* *}$ \\
\hline & (4) & $22.47^{* * *}$ & $40.13^{* * *}$ & 34.1 & & & & 2.890 & $7 \cdot 326$ \\
\hline \multirow[t]{4}{*}{ Romania } & (1) & $-10.01 * * *$ & $-11.90^{* * *}$ & -1.03 & & -1 & & $-0.808^{*}$ & -1.230 \\
\hline & (2) & $-3.827^{* * *}$ & $-4 \cdot 327^{* * *}$ & 0.56 & & & & 0.882 & -0.057 \\
\hline & (3) & $66.56^{* * *}$ & $70.47^{* * *}$ & 21.3 & & & & 27.21 & 32.95 \\
\hline & (4) & $116.2^{* * *}$ & $121.0^{* * *}$ & 58.2 & & & $5^{* *}$ & $47.22^{* *}$ & $65.87^{* *}$ \\
\hline
\end{tabular}

Nотеs Row headings are as follows: (1) Levin, Lin, and Chu $t^{*},(2) \mathrm{Im}$, Pesaran, and Shin W-stat, (3) ADF - Fisher Chi-square, (4) PP - Fisher Chi-square.

tests to understand the characteristics of our panel, to apply adequate panel unit root tests (table 3). All tests (Friedman 1937; Frees 1995; Pesaran 2004) show that the cross-sectional independence can be accepted, and we may apply first-generation panel unit root tests.

For Hungary, the panel unit root tests from the first generation indicate that profitability series are stationary (table 4). However, the opposite applies for the liquidity ratios, while for the solvency ratio we document mixed findings. For Romania we obtain similar results. In this case, classic ordinary least square (ous) regressions might generate biased results. Even if not all our series are I(1) we can check the existence of a long-run relationship between profitability on the one hand, and liquidity and solvency on the other hand.

\section{METHODOLOGY}

To test for cointegration, we use Kao's (1999) test designed for strictly homogenous panels. This test assumes cross-section specific intercepts and homogeneous coefficients on the first-stage regressors. Given that our panels include companies from the same sector (companies that have similar performances and business models), we can rely on Kao (1999) to investigate the existence of a long-run relationship. 
We consider a general three-term regression:

$$
y_{i, t}=\alpha_{i, t}+\beta_{i, t} x_{i, t}+\gamma_{i, t} z_{i, t}+u_{i, t}
$$

where $i=1, \ldots, N$ are the cross-sections, $t=1, \ldots, T$ are the observations (years in our case), $\alpha_{i, t}$ are the individual constant terms $\beta_{i, t}$ and $\gamma_{i, t}$ are slope parameters, and $u_{i, t}$ are error terms.

We therefore have:

$$
\begin{aligned}
& y_{i, t}=y_{i, t-1}+\vartheta_{i, t}, \\
& x_{i, t}=x_{i, t-1}+\varepsilon_{i, t} \\
& z_{i, t}=z_{i, t-1}+\mu_{i, t},
\end{aligned}
$$

where $\vartheta_{i, t}, \varepsilon_{i, t}$ and $\mu_{i, t}$ are the stationary disturbance terms and therefore, $y_{i, t}, x_{i, t}$ and $z_{i, t}$ are integrated process of order 1 for all $i$.

The null of no cointegration $\left(\rho_{i=1}\right)$ is tested performing an ADF unit root test on residuals:

$$
u_{i, t}=\rho_{i} u_{i t-1}+w_{i t} .
$$

If the long-run relationship is documented, it can be tested using a modified version of the oLs regression that produce asymptotically unbiased coefficient estimates. For this purpose, we use the Dols, which involves augmenting the cointegrating regression with lags and leads for the explanatory variables (the choice of lags and leads is made using information criteria).

The tested equation became:

$$
\begin{aligned}
\operatorname{ROEni}_{i, t}= & \alpha_{i, t}+\beta_{1, i} \mathrm{LR}_{i, t}+\sum_{k=-k_{i}}^{k_{i}} \vartheta_{1 i k} \Delta \mathrm{LR}_{i t}+\gamma_{1, i} \operatorname{SOLV}_{i, t} \\
& +\sum_{k=-k_{i}}^{k_{i}} \pi_{1 i k} \Delta \operatorname{SER} R_{i, t}+u_{i, t} .
\end{aligned}
$$

An alternative specification is the FmoLs designed for heterogenous panels by Pedroni (2000). The model is:

$$
\operatorname{ROEni}_{i, t}=\alpha_{i, t}+\beta_{1, i} \mathrm{LR}_{i, t}+\gamma_{1, i} \operatorname{SER}_{i, t}+u_{i, t} .
$$

\section{Empirical Results}

Kao's (1999) cointegration test shows that in all the cases the null hypothesis of no cointegration is rejected (table 2). Therefore, we admit the existence of a long-run relationship. Two models are tested for each country, namely Model 1 (considering LR) and Model 2 (considering CR for liquidity). 
TABLE 5 Kao's (1999) Cointegration Test: Main Results

\begin{tabular}{lcccccc}
\hline Variable & & \multicolumn{2}{c}{ Hungary } & & \multicolumn{2}{c}{ Romania } \\
\cline { 3 - 4 } \cline { 6 - 7 } & & Model 1 & Model 2 & & Model 1 & Model 2 \\
\hline ROEni & ADF & $-2.876^{* * *}$ & $-1.542^{*}$ & & $-2.776^{* * *}$ & $-2.785^{* * *}$
\end{tabular}

NOTES Notes: Ho - no cointegration. ${ }^{*},{ }^{* *}$, and ${ }^{* *}$, mean existence of cointegration at $10 \%, 5 \%$ and $1 \%$, respectively. Model 1 assumes LR for liquidity, while Model 2 considers CR.

TABLE 6 Panel DoLs: Main Results

\begin{tabular}{llccccc}
\hline Variable & & \multicolumn{2}{c}{ Hungary } & & \multicolumn{2}{c}{ Romania } \\
\cline { 3 - 4 } \cline { 6 - 7 } & & Model 1 & Model 2 & & Model 1 & Model 2 \\
\hline \multirow{2}{*}{ ROEni } & LR & $-6.611^{*}$ & & & -0.428 & \\
& CR & & $-6.834^{*}$ & & & -1.816 \\
& SE R & -0.604 & -0.558 & & $-0.341^{*}$ & -0.265 \\
\hline
\end{tabular}

Notes ***, and *** mean statistic relationship significant at $10 \%, 5 \%, 1 \%$, respectively. Pooled mean panel estimator for homogenous panels is used. Schwarz information criterion for lag and lead selection is employed. LR - liquidity ratio (general), $\mathrm{CR}$ - current ratio, SER - capitalization ratio.

In what follows, we apply the panel Dous estimator and we discover that, for Hungary there is a trade-off between profitability and liquidity, and this result is obtain either we use LR or CR for estimating the liquidity level. At the same time, the solvency ratio has no significant effect on profitability. More exactly, under Model 1, an increase of liquidity ratio (LR) with $1 \%$ generates a decrease in the profitability level of $6.61 \%$. Opposite findings are obtained for Romania, where a higher liquidity does not necessary have a negative impact on profitability. On contrary, the solvency ratio negatively influences the level of profitability, but this result is obtained only for Model 1. In this case, an increase in the solvency ratio with $1 \%$, generates a decrease of $0.34 \%$ in the profitability level.

Table 7 presents the results of the Fmols estimator. In this case, none of the coefficients are significant, although the signs remain the same as in the Dols analysis. Given the reduced level of significance for the obtained coefficients reported in table 6 , a series of robustness checks are applied in the next section.

\section{Robusness Analysis}

Two sets of analyses are performed to check the robustness of the previous findings. First, even if the profitability is assessed through the same ROE, we consider this time the profit before tax and not the net income in the denominator. Second, we estimate the profitability 
TABLe 7 Panel Fmols: Main Results

\begin{tabular}{llccccc}
\hline Variable & & \multicolumn{2}{c}{ Hungary } & & \multicolumn{2}{c}{ Romania } \\
\cline { 3 - 3 } & & Model 1 & Model 2 & & Model 1 & Model 2 \\
\hline \multirow{2}{*}{ ROEni } & LR & -0.325 & & & -0.218 & \\
& CR & & -0.248 & & -0.178 \\
& SE R & -0.739 & -0.706 & & -0.217 & -0.224 \\
\hline
\end{tabular}

Notes ***, and ${ }^{* *}$ mean statistic relationship significant at $10 \%, 5 \%, 1 \%$, respectively. Pooled mean panel estimator for homogenous panels is used. Schwarz information criterion for lag and lead selection is employed. LR - liquidity ratio (general), CR - current ratio, SER - capitalization ratio.

TABLE 8 Kao's (1999) Cointegration Test: Robustness Results

\begin{tabular}{llccccc}
\hline Variable & & \multicolumn{2}{c}{ Hungary } & & \multicolumn{2}{c}{ Romania } \\
\cline { 3 - 4 } \cline { 6 - 7 } & & Model 1 & Model 2 & & Model 1 & Model 2 \\
\hline ROEpbt & ADF & -0.988 & 0.461 & & $-2.460^{* * *}$ & $-2.451^{* * *}$ \\
ROApbt & ADF & $2.266^{* *}$ & $1.820^{* *}$ & & -0.170 & -0.201 \\
\hline
\end{tabular}

NOTES Notes: но - no cointegration. *, **, and ${ }^{* * *}$, mean existence of cointegration at $10 \%, 5 \%$ and $1 \%$, respectively. Model 1 assumes LR for liquidity, while Model 2 considers CR.

with ROA, considering the profit before tax (ЕВIT). We start the analysis with the Kao's (1999) cointegration test (table 7), which documents the existence of a long-run relationship between our variables, for Hungary (when RoApbt is the dependent variable) and for Romania (when Roepbt is the dependent variable).

We continue the analysis with the Dols estimator, and we test the regression only for those cases where the cointegrating relationship was documented (table 9). For Hungary, we obtain similar findings with those reported in table 6 . While the liquidity negatively influences the level of profitability, the capitalization ratio has no significant impact. For Romania, an opposite situation appears, confirming our main findings. While liquidity does not influence the profitability level, capitalization has a negative impact for both models. Our findings can be thus considered robust relative to the way we compute the profitability level. Therefore, these results recommend different financial management strategies for companies acting in the public administration and defense sector in Hungary and Romania.

We continue our analysis with the FMoLs estimator applied for robustness check. The FMols results confirm the Dols findings for Romania, showing the negative and significant impact of capitalization ratio on profitability. This means that Romanian firms which resort to internal financing sources have a smaller level of profitability 
TABLE 9 Panel Dols: Robustness Results

\begin{tabular}{|c|c|c|c|c|c|}
\hline \multirow[t]{2}{*}{ Variable } & & \multicolumn{2}{|c|}{ Hungary } & \multicolumn{2}{|c|}{ Romania } \\
\hline & & Model 1 & Model 2 & Model 1 & Model 2 \\
\hline \multirow[t]{3}{*}{ ROEpbt } & LR & & & 1.138 & \\
\hline & $\mathrm{CR}$ & & & & -0.634 \\
\hline & SER & & & $-0.697^{* * *}$ & $-0.593^{*}$ \\
\hline \multirow[t]{3}{*}{ RoApbt } & LR & $-5.114^{* *}$ & & & \\
\hline & CR & & $-5.648^{* *}$ & & \\
\hline & SER & 0.000 & 0.045 & & \\
\hline
\end{tabular}

Notes $*{ }^{* *}$, and ${ }^{* * *}$ mean statistic relationship significant at $10 \%, 5 \%, 1 \%$, respectively. Pooled mean panel estimator for homogenous panels is used. Schwarz information criterion for lag and lead selection is employed. LR - liquidity ratio (general), $\mathrm{CR}$ - current ratio, SER - capitalization ratio.

TABLE 10 Panel FMOLS: Robustness Results

\begin{tabular}{|c|c|c|c|c|c|}
\hline \multirow[t]{2}{*}{ Variable } & & \multicolumn{2}{|c|}{ Hungary } & \multicolumn{2}{|c|}{ Romania } \\
\hline & & Model 1 & Model 2 & Model 1 & Model 2 \\
\hline \multirow[t]{3}{*}{ ROEpbt } & LR & & & 0.949 & \\
\hline & $\mathrm{CR}$ & & & & 0.751 \\
\hline & SER & & & $-0.499^{* *}$ & $-0.490^{*}$ \\
\hline \multirow[t]{3}{*}{ RoApbt } & LR & -0.272 & & & \\
\hline & $\mathrm{CR}$ & & -0.242 & & \\
\hline & SER & -0.025 & -0.015 & & \\
\hline
\end{tabular}

Notes * **, and *** mean statistic relationship significant at $10 \%, 5 \%, 1 \%$, respectively. Pooled mean panel estimator for homogenous panels is used. Schwarz information criterion for lag and lead selection is employed. LR - liquidity ratio (general), $\mathrm{CR}$ - current ratio, SER - capitalization ratio.

compared to more leveraged companies. While the FmoLs findings do not confirm the Dous findings in our robustness analysis for Hungary, we notice that they confirm the main results reported in table 7 . The FmoLs analysis shows that the liquidity and capitalization ratios have no significant influence on the profitability level for Hungary.

All in all, we may conclude that our results are robust to different metrics used to compute the profitability and liquidity level. However, the findings reported by the Dous and Fmols estimators are robust for Romania only.

\section{Conclusions}

This paper tests the role of liquidity and capitalization in enhancing the profitability level of firms acting in the public administration and defense sector, performing a comparison between Hungary and 
Romania, two neighbors, post-communist countries. To this end, we use firm-level data for the period 2006 to 2015, considering 17 firms from Romania and 11 from Hungary.

We perform a panel cointegration analysis and we discover several differences between the analyzed countries. On the one hand, we notice a trade-off between profitability and liquidity in Hungary, but not for Romania. On the other hand, we discover that the financing structure does not influence the profitability in Hungary. However, an increased capitalization has a negative impact on profitability for companies acting in the public sector in Romania. These findings are robust to different specifications for the profitability and liquidity ratios, and partially robust when we compare the results of the DoLs and FMOLs estimators.

Our results add to previous empirical findings investigating the profitability - liquidity nexus, and shows that, in general, unemployed resources negatively influence the level of firms' profitability. At the same time, for the financial management of companies located in Hungary, and acting in the public administration and defense sector, it is important to know that an increased liquidity triggers a smaller profitability level. Therefore, we may assume that the Hungarian companies did not benefited from new investment opportunities in the post-crisis period, opportunities which usually help liquid firms to quickly adapt to new market conditions. For the Romanian companies, the level of liquidity has no significant influence on profitability (a similar result was reported by Smith and Begemann (1997) for a set of South African firms). However, a higher capitalization ratio for companies acting in the analyzed sector from Romania, negatively influences the level of profitability. This result shows that internal financing sources are more expensive compared with the external ones and it is opposed to the findings advanced by Ghosh (2008).

The findings of our paper should, however, be considered with caution. On the one hand, the level of coefficient significance is reduced, and the relationship between profitability and liquidity is not straightforward. On the other hand, our estimation may suffer for the omitted variable bias. As we have presented in Introduction, the relationship between the profitability and liquidity, as well as the relationship between profitability and capitalization, might be influenced by the leverage level of companies. At the same time, given the particularities of the analyzed sector, the findings may be influenced by the business cycle, public investment but also by the level of corruption characterizing these countries. The profitability of firms act- 
ing in the public sector and defense sector increase when the access to public contracts is facilitated. Therefore, the institutional characteristics of these countries might influence the empirical findings and requires additional investigations.

\section{Acknowledgements}

This work was supported by a grant of the Romanian National Authority for Scientific Research and Innovation, CNCS-UEFISCDI, project number PN-II-RU-TE-2014-4-1760.

\section{References}

Adhikary, S., and G. Papachristou. 2017. 'Determinants of Profitability in South Asian Microfinance Institutions.' Journal of Global Economics, Management \& Business Research 8:76-87.

Akinlo, O. O. 2011. 'Does Working Capital Cause Profitability? The Nigerian Experience.' Journal of Modern Accounting and Auditing 7:457462 .

- 2012. 'Effect of Working Capital on Profitability of Selected Quoted Firms in Nigeria.' Global Business Review 13:367-381.

Albulescu, C. T., S. Miclea, M. Tamasila, and I. M. Taucean. 2016. 'The Working Capital and Liquidity's Role in Explaining the Italians' Firms Profitability around the Recent Financial Crisis.' Paper presented at the 5th Review of Management and Economic Engineering International Management Conference, Cluj Napoca, 22-24 September.

Bolek, M., and R. Wolski. 2012. 'Profitability or Liquidity: Influencing the Market Value; The Case of Poland.' International Journal of Economics and Finance 4:182-190.

Deloof, M. 2003. 'Does Working Capital Management Affect Profitability of Belgian Firms?' Journal of Business Finance and Accounting 30:573-587.

Frees, E. W. 1995. 'Assessing Cross-Sectional Correlation in Panel Data.' Journal of Econometrics 69:393-414.

Friedman, M. 1937. 'The Use of Ranks to Avoid the Assumption of Normality Implicit in the Analysis of Variance.' Journal of the American Statistical Association 32:675-701.

Ghosh, S. 2008. 'Leverage, Foreign Borrowing and Corporate Performance: Firm-Level Evidence for India.' Applied Economic Letters 15:607-616.

Gill, A., N. Bigger, and N. Mathur. 2010. 'The Relationship between Working Capital Management and Profitability: Evidence from the United States.' Business and Economics Journal 2:1-9.

Kao, C. 1999. 'Spurious Regression and Residual-Based Tests for Cointegration in Panel Data.' Journal of Econometrics 90:1-44.

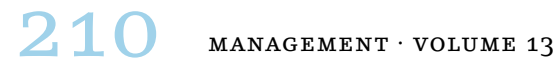


Kao, C., and M.-H. Chiang. 200o. 'On the Estimation and Inference of a Cointegrated Regression in Panel Data.' In Advances in Econometrics: Nonstationary Panels, Panel Cointegration and Dynamic Panels 15, edited by B. H. Baltagi and C. Kao, 179-222. Amsterdam: Elsevier.

Korajczyk, R. A., and A. Levy. 2003. 'Capital Structure Choice: Macroeconomic Conditions and Financial Constraints.' Journal of Financial Economics 68:75-109.

Iqbal, A., J. Mulani, and S. Kabiraj. 2013. 'Leverage, Size of the Firm and Profitability: A Case of Pakistani Cement Industry.' International Journal of Business Insights \& Transformation 7:16-22.

Murphy, J. 1968. 'Effect of Leverage on Profitability, Growth and Market Valuation of Common Stock.' Financial Analysts Journal 24:121-123.

Pedroni, P. 2000. 'Fully Modified ols for Heterogeneous Cointegrated Panels.' Advances in Econometrics 15:93-130.

Perobelli, F. F. C., R. Famá, and L. C. Sacramento. 2016. 'Return and Liquidity Relationships on Market and Accounting Levels in Brazil.' Revista Contabilidade \& Finanças 27:259-272.

Pesaran, M. H. 2004. 'General Diagnostic Tests for Cross Section Dependence in Panels.' Cambridge Working Papers in Economics 0435, University of Cambridge, Cambridge.

Raheman, A., and M. Nasr. 2007. 'Working Capital Management and Profitability: Case of Pakistani Firms.' International Review of Business Research Papers 3:279-300.

Smith, M. B., and E. Begemann. 1997. 'Measuring Association between Working Capital and Return on Investment.' South African Journal of Business Management 28:1-5.

Ukaegbu, B. 2014. 'The Significance of Working Capital Management in Determining Firm Profitability: Evidence from Developing Economies in Africa.' Research in International Business and Finance 31:116.

Wasiuzzaman, S. 2015. 'Working Capital and Profitability in Manufacturing Firms in Malaysia: An Empirical Study.' Global Business Review 16:545-556.

This paper is published under the terms of the Attribution-

NonCommercial-NoDerivatives 4.o International (CC BY-NC-ND 4.0)

License (http://creativecommons.org/licenses/by-nc-nd/4.o/). 